\title{
Pengaruh Tepung Kulit Pisang Kepok (Musa Paradisiaca L.) terhadap Aktivitas Antioksidan dan Sitotoksisitas pada Sel Kanker Payudara T-47D
}

\author{
Zhafirah Salma Putri ${ }^{1}$, Reyna Rachma Wati ${ }^{1}$, Rahma MichoWidyanto ${ }^{1}$, Yosfi Rahmi ${ }^{1}$, Wahyu Diah \\ Proborini ${ }^{2}$ \\ ${ }^{1}$ Program Studi Ilmu Gizi, Fakultas Kedokteran, Universitas Brawijaya (UB), \\ Jl. Veteran, Ketawanggede, Kec. Lowokwaru, Malang, Jawa Timur 65145 \\ ${ }^{2}$ Jurusan Teknik Kimia, Fakultas Teknik Universitas Tribhuwana Tunggadewi \\ Jl. Telaga Warna, Tlogomas, Malang, Jawa Timur, Indonesia, 65144
}

Penulis untuk Korespondensi/E-mail: firaawhyd@student.ub.ac.id

Abstrak - Kanker payudara masih menjadi permasalahan kesehatan yang kompleks. Salah satu upaya untuk mengatasi kanker adalah dengan konsumsi makanan tinggi kandungan antioksidan. Bahan pangan alternatif potensial adalah kulit pisang kepok yang mengandung senyawa fitokimia kaya antioksidan.Tepung kulit pisang belum banyak dimanfaatkan dan belum diteliti kandungan antioksidan serta potensi antikankernya. Penelitian ini bertujuan untuk melihat nilai aktivitas antioksidan, toksisitas, dan efek sitotoksisitas terhadap sel T-47D secara in vitro. Kulit dari pisang kepok matang direndam dalam larutan $1 \% \mathrm{Na}_{2} \mathrm{~S}_{2} \mathrm{O}_{5}$ selama 15 menit, dikeringkan dalam oven kabinet pada suhu $60^{\circ} \mathrm{C}$ selama 7 jam, dihancurkan menggunakan blender, dan diayak menggunakan ayakan 80 mesh. Uji aktivitas antioksidan dilakukan dengan metode DPPH (2,2-difenil-1-pikrillhidrazil), uji toksisitas menggunakan metode BSLT (Brine Shrimp Lethality Test) serta uji sitotoksisitas dilakukan menggunakan MTT assay(3-(4, 5-dimetiltiazol-2-il)-2, 5-difeniltetrazolium bromid).Hasil aktivitas antioksidan didapatkan nilai $\mathrm{IC}_{50} 237,684 \mathrm{ppm}$ yang menunjukkan aktivitas antioksidan bersifat sangat lemah, hasil uji toksisitas adalah $\mathrm{LC}_{50} 4.665,77 \mathrm{ppm}$ yang menunjukkan tidak bersifat toksik bagi larva Artemia salina L. serta hasil $\mathrm{IC}_{50} \mathrm{uji}$ sitotoksisitas adalah $720.396 \mu \mathrm{g} / \mathrm{ml}$ yang menunjukkan efek sitotoksisitas lemah sehingga tepung kulit pisang kepok tidak berpotensi sebagai antikanker terhadap sel T-47D.

Abstract - Breast cancer still becomes a complex health problem. One of the attempts to overcome cancer is by consuming high antioxidants foods. Potential alternative food is kepok banana peels which contain phytochemical compounds rich in antioxidants. Banana peel flour has not been widely used and has not yet been studied its antioxidant content and anti-cancer potential. This study aimed to see the value of the antioxidant activity, toxicity, and cytotoxicity effects on T-47D cells in vitro. The peel of ripe kepok banana was soaked in $1 \% \mathrm{Na} 2 \mathrm{~S} 2 \mathrm{O} 5$ solution for 15 minutes, dried in a cabinet oven at $60^{\circ} \mathrm{C}$ for 7 hours, grounded using a blender, and sieved using an 80 mesh sieve. The antioxidant activity test was carried out by the DPPH (2,2-diphenyl-1-pikrillhidrazil) method, the toxicity test used the BSLT (Brine Shrimp LethalityTest) method and the cytotoxicity test was carried out using the MTT assay (3- (4, 5dimethyltiazol-2-il ) -2,5-diphenyl tetrazolium bromide). The antioxidant activity test results were IC50at 237,684 ppm which showed weak antioxidant activity, the toxicity test results were LC50at4,665.77ppm which showed no toxic effects for Artemia salina L. larvae and cytotoxicity test results were IC50at $720,396 \mu \mathrm{g} / \mathrm{ml}$ which showed a weak cytotoxicity effect indicating that kepok banana peel flour has no potential as an anticancer against T-47D cells.

Keywords -Tepung kulit pisang kepok, Antioksidan, Sitotoksisitas, BSLT, Kanker payudara, T-47D 


\section{PENDAHULUAN}

Indonesia merupakan salah satu penghasil pisang terbesar di dunia yang pada tahun 2014 menghasilkan 6.862.558 ton [1]. Pisang kepok (Musa paradisiaca Linn) yang merupakan anggota dari keluarga Musaceae merupakan salah satu jenis pisang yang paling banyak dihasilkan. Pisang kepok adalah jenis pisang yang mudah ditemui, dengan ciri berkulit kuning kehijauan dengan bercak coklat, berbentuk agak pipih dan bersegi, serta kulit buahnya yang tebal. Kulit pisang kepok memiliki rasa berpati hingga manis [2]. Pisang kepok merupakan salah satu jenis pisang yang pemanfaatannya paling sering diolah terlebih dahulu sebelum dikonsumsi, misal diolah menjadi bahan utama pisang goreng, sale, maupun keripik pisang, baik yang memiliki rasa manis maupun gurih [3].

Tingginya jumlah produksi pisang di Indonesia diikuti dengan jumlah kulit pisang yang dihasilkan, yaitu mencapai 2.063.017 ton/tahun [4]. Salah satu kandungan gizi yang dapat diunggulkan dari pemanfaatan kulit pisang kepok (Musa paradisiaca L.) adalah kandungan karbohidratnya yang cukup banyak, yakni 59\% [5]. Pembuatan tepung kulit pisang kepok dapat dimanfaatkan sebagai bahan pangan juga sebagai upaya alternatif untuk mengurangi limbah kulit pisang. Secara umum kulit pisang mengandung senyawa tinggi antioksidan seperti fenol, katekolamid, karoten dan flavonoid, polifenol, vitamin C, dan tannin [6] [7]. Banyaknya kandungan nutrisi dalam kulit pisang kepok, menjadikan kulit pisang kepok sangat berpotensi untuk diolah menjadi pangan fungsional melalui pengolahan menjadi tepung.

Selain itu, tepung kulit pisang kepok berpotensi sebagai antikanker melalui mekanisme aktivasi jalur apoptosis dan mengganggu DNA sel kanker [8]. Mekanisme ini muncul didukung oleh kandungan fitokimia golongan fenolik yang terdapat pada kulit pisang kepok seperti polifenol, tannin, dan flavonoid [9] [6]. Pemanfaatan tepung kulit pisang kepok sebagai antikanker ini dapat menjadi salah satu solusi untuk tingginya kejadian kanker di Indonesia, yaitu terdapat 347.792 kasus kanker dengan 58.256 diantaranya adalah kanker payudara sebagai jenis kanker nomor satu di Indonesia [10].
Beberapa penelitian telah mengkaji kandungan fitokimia golongan fenolik pada berbagai macam tepung kulit pisang dengan metode yang bervariasi. Tepung kulit pisang kepok mengandung polifenol sebesar 7,71 mg GAE/g dan tannin sebesar 30,98 $\mathrm{mg}$ GAE/g dengan metode pemanasan pada suhu $40^{\circ} \mathrm{C}$ selama 48 jam [9]. Selain itu, pada metode ekstraksi menggunakan etil asetat ditemukan kandungan kandungan fenolik dan flavonoid sebesar 15,21 dan 9,39 mg QE/g berat kering pada tepung kulit pisang Nendran [11].

Penelitian terdahulu menunjukkan bahwa tepung kulit pisang dapat berpotensi sebagai antikanker, meskipun belum ada penelitian yang menunjukkan pengujian sitotoksisitas terhadap sel kanker. Oleh karena itu, peneliti ingin melakukan uji aktivitas antioksidan dan toksisitas serta uji sitotoksisitas tepung kulit pisang kepok (Musa paradisiaca Linn) terhadap sel kanker payudara T-47D dengan metode MTT Assay secara in vitro.

\section{METODE PENELITIAN}

\section{Persiapan dan Produksi Kulit Pisang Kepok}

Kulit pisang kepok yang digunakan berasal dari pisang kepok yang didapatkan dari pasar Sawojajar, Malang, Jawa Timur. Penepungan kulit pisang kepok dilakukan berdasarkan modifikasi dari penelitian yang dilakukan oleh Futeri dan Pharmayeni [12], dari buah pisang kepok, kulit pisang dikupas dan dipisahkan dari daging buahnya, kulit pisang yang digunakan adalah kulit pisang yang berasal dari buah pisang kepok yang masak, kemudian dibersihkan dan dicuci, kulit pisang kepok dipotong dengan sayatan melintang dan direndam dengan larutan natrium metabisulfit $\left(\mathrm{Na}_{2} \mathrm{~S}_{2} \mathrm{O}_{5}\right) 1 \%$ selama 15 menit dan ditiriskan, kulit pisang kepok dikeringkan pada suhu $60^{\circ} \mathrm{C}$ selama 7 jam, kemudian kulit pisang kepok dihaluskan menggunakan blender, dan diayak dengan ayakan berukuran 80 mesh.

\section{Aktivitas Antioksidan}

Uji aktivitas antioksidan dilakukan di Laboratorium Teknik Kimia Universitas Tribuwhana Tunggadewi, Malang. Aktivitas antioksidan diuji menggunakan reagen DPPH $(2,2$ - difenil - 1 pikrillhidrazil). Pengukuran aktivitas antioksidan dilakukan berdasarkan modifikasi dari penelitian yang dilakukan oleh Tristantini dkk [13], uji dilakukan dengan menambahkan $2 \mathrm{mg}$ DPPH ke dalam $100 \mathrm{ml}$ methanol. Larutan kontrol negatif dibuat dengan menambahkan 5,9 $\mathrm{ml}$ methanol 
dengan 0,1 ml DMSO dan $4 \mathrm{ml}$ larutan DPPH, sedangkan larutan kontrol positif dibuat dengan melarutkan asam askorbat ke dalam methanol dengan variasi konsentrasi 4 ppm, 8 ppm, dan 16 ppm. Masing-masing konsentrasi diambil $6 \mathrm{ml}$ dan dicampurkan dengan $4 \mathrm{ml}$ DPPH. Larutan sampel dibuat dengan konsentrasi 100 ppm, 200 ppm, dan 400 ppm dari tepung kulit pisang kepok yang dilarutkan dengan DMSO 2\% dan metanol serta divortex terlebih dahulu. Kemudian ditambahkan 6 $\mathrm{ml}$ dari masing-masing larutan sampel dan $4 \mathrm{ml}$ DPPH. Larutan sampel dan kontrol diinkubasi di ruangan gelap dan tabung reaksi dilapisi menggunakan alumunium foil selama 30 menit. Setelah itu, pengukuran dilakukan dengan membaca absorbansi menggunakan spektrofotometer pada panjang gelombang $517 \mathrm{~nm}$, menghitung persentasi penghambatan dari absorbansi sampel dan kontrol negatif dengan menggunakan persamaan:

$\%$ Penghambatan $=(\mathrm{Ab}-\mathrm{As} / \mathrm{Ab}) \times 100$

Nilai $\mathrm{IC}_{50}$ didapatkan dari persamaan grafik persen penghambatan dan konsentrasi.

\section{Uji Toksisitas}

Uji toksisitas dilakukan di Laboratorium Teknik Kimia Universitas Tribuwhana Tunggadewi, Malang. Toksisitas tepung kulit pisang kepok diuji dengan metode Brine Shrimp Lethality Test (BSLT) dilakukan berdasarkan modifikasi dari penelitian yang dilakukan oleh Arwan [14]. Telur Artemia salina sebanyak 5 gram dimasukkan ke dalam 1 liter air di dalam tabung yang berbentuk kerucut pada bagian bawahnya terdapat aerator yang tersambung dengan kerucut tersebut sebagai sumber udara. Air tersebut sebelumnya sudah ditambahkan 60 gram $\mathrm{NaCl}$ dan 1/4 $\mathrm{sdm}$ bakingsoda untuk meningkatkan $\mathrm{pH}$ air. Lampu yang terletak 6 inci dari tabung dinyalakan sebagai sumber cahaya, telur dibiarkan selama 24-36 jam sampai menetas, dan siap digunakan setelah 48 jam, setelah larva menetas, aerator dimatikan agar larva menuju bagian bawah tabung yang dekat dengan lampu sebagai sumber cahaya.

Larva yang telah menetas dipindah ke wadah lain dengan cara melepas sambungan selang aerator pada kerucut, dan kumpulan larva akan keluar melalui lubang kerucut, masing-masing sampel dibuat pada konsentrasi 2000 ppm, 4000 ppm, dan $8000 \mathrm{ppm}$ yang dilarutkan dengan $0,1 \mathrm{ml}$ DMSO dan $5 \mathrm{ml}$ air garam $60 \%$, masing-masing larutan disentrifuse dengan kecepatan $1000 \mathrm{rpm}$ selama 15 menit, kemudian 10 ekor larva dimasukkan menggunakan pipet ke dalam tabung reaksi yang berisi supernatan dari masing-masing larutan dan ke dalam larutan kontrol yang berisi air garam $60 \%$ dan 2 tetes DMSO, selanjutnya larva dibiarkan selama 24 jam dan dihitung total kematiannya. Percobaan dilakukan secara triplo. $\mathrm{LC}_{50}$ didapatkan dengan meng-antilog-kan nilai $\mathrm{X}$ pada persamaan grafik yang berisi log konsentrasi dan probit persen kematian larva Artemia salina.

\section{Uji Sitotoksisitas}

Uji sitotoksisitas tepung kulit pisang kepok menggunakan metode MTT Assay terhadap sel kanker payudara T-47D secara in vitro yang dilakukan di Laboratorium Teknologi Bioindustri Serpong, Tangerang Selatan. Sampel tepung kulit pisang kepok dilarutkan menggunakan DMSO dan dibuat seri konsentrasi sampel tepung kulit pisang kepok yaitu $125 ; 250 ; 500 ;$ dan $1000 \mu \mathrm{l} / \mathrm{ml}$. Kontrol positif yang digunakan adalah Cisplatin dengan seri konsentrasi 3; 6; 9; dan $12 \mu \mathrm{l} / \mathrm{ml}$. Seri konsentrasi sampel tepung kulit pisang kepok dan cisplatin dimasukkan ke dalam sumuran yang berisi sel $\mathrm{T}$ 47D secara triplo. Lama waktu inkubasi sel T-47D adalah 1 1 24 jam, kemudian reagen MTT ditambahkan ke setiap sumuran. Stopper SDS ditambahkan apabila formazan sudah terbentuk dan dilakukan inkubasi kembalu dalam kondisi gelap pada suhu kamar selama semalaman. Pembacaan absorbansi penghambatan proliferasi dapat dilihat menggunakan ELISA reader dengan panjang gelombang $570 \mathrm{~nm}$. Data absorbansi yang diperoleh dianalisis menggunakan regresi linier yaitu dengan pembuatan grafik konsentrasi dengan persentase sel hidup. Setelah itu didapatkan persamaan regresi linier untuk menghitung nilai $\mathrm{IC}_{50}$ dari tepung kulit pisang kepok dan Cisplatin.

\section{HASIL DAN PEMBAHASAN}

\section{Tepung Kulit Pisang Kepok}

Tepung kulit pisang kepok yang telah didapatkan bertekstur halus berpasir dan berwarna coklat, serta dalam 1.000 gram atau 1 kilogram kulit pisang kepok dapat dihasilkan sebanyak 15 gram tepung kulit pisang kepok.

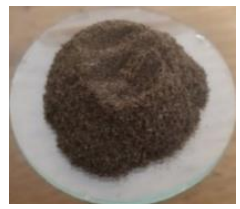

Gambar 1 Tepung Kulit Pisang Kepok 
Pada penelitian ini, pembuatan tepung kulit pisang kepok dilakukan dengan perendaman menggunakan natrium metabisulfit terlebih dahulu untuk meminimalisir pencoklatan pada kulit pisang kepok, karena natrium metabisulfit merupakan bahan tambahan pangan (BTP) yang berguna sebagai anti pencoklatan [15]. Reaksi pencoklatan pada kulit pisang kepk merupakan reaksi pencoklatan enzimatis yang dapat terjadi saat kulit pisang kepok dikupas kemudian bereaksi dengan oksigen, sehingga enzim Polifenol Oksidase (PPO) membentuk dua reaksi, yaitu hidroksilasi monofenol dan oksidasi ortho-difenol yang akan menjadi ortho-quinon menyebabkan pencoklatan, reaksi pencoklatan enzimatis pada kulit pisang dapat dihambat oleh natrium metabisulfit dimana sulfit akan mereduksi ikatan disulfida pada enzim PPO, sehingga enzim PPO tidak dapat mengkatalisis oksidasi senyawa fenolik atau reaksi searah enzim PPO yang akan menjadi ortho-quinon berwarna sebagai penyebab pencoklatan akan terhambat, atau melalui mekanisme lain. Sulfit akan bertindak sebagai agen pereduksi yang akan mengembalikan reaksi ortho-quinon menjadi difenol tidak berwarna [16] [17].

Pengeringan kulit pisang kepok menggunakan oven membuat kulit pisang kepok lebih cepat kering dan higienis daripada pengeringan langsung menggunakan sinar matahari yang lebih mudah terkontaminasi bakteri maupun kapang, Pengeringan langsung di bawah sinar matahari selama 12 jam terkontaminasi 67.500 koloni bakteri per gram, dan untuk pengeringan menggunakan oven selama 12 jam terdapat 2.500 koloni bakteri/gram [18].

\section{Aktivitas Antioksidan}

Tabel 1. Hasil Pengukuran Absorbansi, Persen

Penghambatan, dan nilai $\mathrm{IC}_{50}$ Tepung Kulit Pisang Kepok

\begin{tabular}{ccccc}
\hline $\begin{array}{c}\text { Kons. } \\
\text { (ppm) }\end{array}$ & Absorbansi & $\begin{array}{c}\text { A. } \\
\text { Kontrol }\end{array}$ & \% Inhibisi & $\begin{array}{c}\mathbf{I C}_{\mathbf{5 0}} \\
(\mathbf{p p m})\end{array}$ \\
\cline { 1 - 4 } $\mathbf{1 0 0}$ & 0,12 & 0,18 & 31,67 & \\
\cline { 1 - 4 } $\mathbf{2 0 0}$ & 0,09 & 0,18 & 50,00 & \multirow{2}{2}{237,68} \\
\cline { 1 - 4 } $\mathbf{4 0 0}$ & 0,08 & 0,18 & 58,33 & \\
\hline
\end{tabular}

Pada Tabel 1 menunjukkan bahwa aktivitas antioksidan $\left(\mathrm{IC}_{50}\right)$ kulit pisang kepok sebesar 237,68 ppm atau aktivitas antioksidan bersifat sangat lemah, karena nilai lebih besar dari 200 ppm.
Tabel 2. Hasil Persen Penghambatan, Pengukuran Absorbansi, dan nilai $\mathrm{IC}_{50}$ Asam Askorbat.

\begin{tabular}{ccccc}
\hline $\begin{array}{c}\text { Kons. } \\
\text { (ppm) }\end{array}$ & Absorbansi & $\begin{array}{c}\text { A. } \\
\text { Kontrol }\end{array}$ & \% Inhibisi & $\begin{array}{c}\mathbf{I C}_{\mathbf{5 0}} \\
(\mathbf{p p m})\end{array}$ \\
\cline { 1 - 4 } $\mathbf{4}$ & 0,12 & 0,18 & 32,22 & \\
\cline { 1 - 4 } $\mathbf{8}$ & 0,10 & 0,18 & 44,44 & \multirow{2}{*}{6,81} \\
\cline { 1 - 4 } $\mathbf{1 6}$ & 0,01 & 0,18 & 95,56 & \\
\hline
\end{tabular}

Pada Tabel 2 menunjukkan bahwa aktivitas antioksidan $\left(\mathrm{IC}_{50}\right)$ asam askorbat sebesar 6,81 ppm atau aktivitas antioksidan bersifat sangat kuat, karena nilai lebih kecil dari 50 ppm.

Aktivitas antioksidan yang didapatkan pada tepung kulit pisang kepok sebesar 237,68 ppm atau aktivitas antioksidan bersifat lemah, hal ini dikarenakan sebagian besar kandungan antioksidan pada kulit pisang kepok adalah kelompok flavon dalam bentuk glikosida, dimana bentuk glikosida dalam komponen flavonoid memiliki kemampuan reduksi DDPH yang lemah dibandingkan dengan bentuk aglikon [19] [20]. Kandungan tannin pada tepung kulit pisang kepok adalah jenis tannin terkondensasi dan terhidrolisa [9]. Kandungan tannin terkondensasi lebih besar daripada tannin terhidrolisa. Namun, tannin terkondensasi bekerja kurang efektif dalam menangkap DPPH. Hal tersebut dikarenakan tannin terkondensasi merupakan polimer yang memiliki berat molekul tinggi, sedangkan antioksidan yang memiliki berat molekul rendah akan lebih efektif dalam menangkap DPPH atau radikal bebas. Tannin terhidrolisa yang terdapat dalam pisang kepok adalah jenis asam galat dan asam ellagic, dimana kedua macam tannin terhidrolisa ini tidak dapat dipecah karena berikatan kovalen dengan lignin dan selulosa, sedangkan pemecahan hanya dapat terjadi di usus besar dengan bantuan mikrobiota usus [20] [21].

Selain itu, keberadaan serat pangan dan pati yang cukup tinggi pada tepung kulit pisang kepok dapat mempengaruhi aktivitas antioksidan melalui pemerangkapan komponen fenolik, flavonoid dan antosianin oleh pektin maupun selulosa sebagai serat yang tidak larut air [9]. Tingginya pati dalam tepung kulit pisang kepok juga dapat menyebabkan interaksi fisikokimia dengan memerangkap komponen fenolik dan mengikat tannin terkondensasi yang dapat menyebabkan rendahnya aktivitas antioksidan karena kurangnya jumlah 
komponen fenolik yang dapat menangkap DPPH [19] [22].

Kandungan flavonoid dalam kulit pisang kepok yang diketahui melalui analisa HPLC antara lain asam ellagic, asam galat, rutin, dan myricetin [19]. Dimana keempat zat tersebut termasuk dalam insoluble-bound phenolics atau fenol terikat yang tidak larut atau fenolat yang tidak larut secara kimiawi yang membentuk ikatan kovalen dengan pektin, selulosa, arabionoksi dan protein struktural yang tidak dapat diserap oleh usus kecil, melainkan komponen polifenol akan dilepaskan melalui proses fermentasi di usus besar, kondisi ini dibentuk oleh mikrobiota usus yang dapat mencegah proses oksidatif, menjaga jaringan, dan mengurangi perkembangan resiko kanker usus besar [9].

\section{Uji Toksisitas}

Tabel 3. Besar Konsentrasi dan Persentase Kematian

\begin{tabular}{|c|c|c|c|c|c|c|}
\hline \multirow[t]{2}{*}{$\begin{array}{l}\text { Kons. } \\
(\mathrm{mg} / \mathrm{ml})\end{array}$} & \multicolumn{3}{|c|}{$\begin{array}{c}\text { Jumlah } \\
\text { kematian } \\
\text { pada } \\
\text { Pengulangan } \\
\text { Ke-... }\end{array}$} & \multirow[t]{2}{*}{$\begin{array}{l}\text { Rata-rata } \\
\text { Kematian }\end{array}$} & \multirow[t]{2}{*}{$\begin{array}{c}\% \\
\text { Kematian }\end{array}$} & \multirow[t]{2}{*}{ Probit } \\
\hline & 1 & 2 & 3 & & & \\
\hline 2 & 1 & 2 & 1 & 1,3 & $13 \%$ & 3,87 \\
\hline 4 & 3 & 2 & 2 & 2,3 & $23 \%$ & 4,26 \\
\hline 8 & $\begin{array}{l}1 \\
0\end{array}$ & 10 & 6 & $86,7 \%$ & 6,11 & 6,12 \\
\hline $\begin{array}{l}\text { Kont. } \\
\text { Negatif }\end{array}$ & 0 & 0 & 0 & 0 & $0 \%$ & 0 \\
\hline
\end{tabular}

Hasil penelitian menunjukkan bahwa tepung kulit pisang kepok mempunyai nilai $\mathrm{LC}_{50}$ adalah 4.665 , 77 ppm, sehingga hal ini menunjukkan bahwa tepung kulit pisang kepok tidak bersifat toksik bagi larva udang karena nilai $\mathrm{LC}_{50}>1.000 \mathrm{ppm}$, sedangkan suatu zat dikatakan toksik apabila $\mathrm{LC}_{50} \leq$ $1.000 \mathrm{ppm}$. Penelitian lain yang dilakukan oleh Chrisnasari dkk [23], pada tepung batang pitaya utuh menunjukkan kematian larva sebesar $0 \%$ pada konsentrasi 0 ppm, $250 \mathrm{ppm}, 500 \mathrm{ppm}$, sedangkan pada konsentrasi 1.000 ppm menunjukkan kematian sebesar $6,67 \%$ dan kematian sebesar $16,67 \%$ pada konsentrasi $1.500 \mathrm{ppm}$. Namun, dari hasil yang didapatkan baik pada tepung kulit pisang kepok maupun pada tepung batang pitaya utuh menunjukkan bahwa peningkatan konsentrasi diikuti dengan peningkatan jumlah larva Artemia salina $\mathrm{L}$ yang mati, penambahan tepung kulit pisang kepok telah meningkatkan viskositas medium atau air laut buatan. Peningkatan viskositas medium disebabkan oleh kandungan serat larut air yang tinggi, sehingga menyebabkan peningkatan tekanan osmotik yang dapat mengganggu pergerakan atau motilitas larva.

Di sisi lain, ada kemungkinan terdapat senyawa fitokimia yang terkandung dalam tepung dapat menyebabkan kematian larva Artemia salina L., dari data ini, masih belum dapat disimpulkan apakah toksisitas disebabkan oleh viskositas atau adanya senyawa fitokimia yang ada dalam tepung kulit pisang kepok [23]. Senyawa fitokimia yang ada di dalam kulit pisang kepok antara lain adalah alkaloid, flavonoid, fenol dan tannin [24].

\section{Uji Sitotoksisitas}

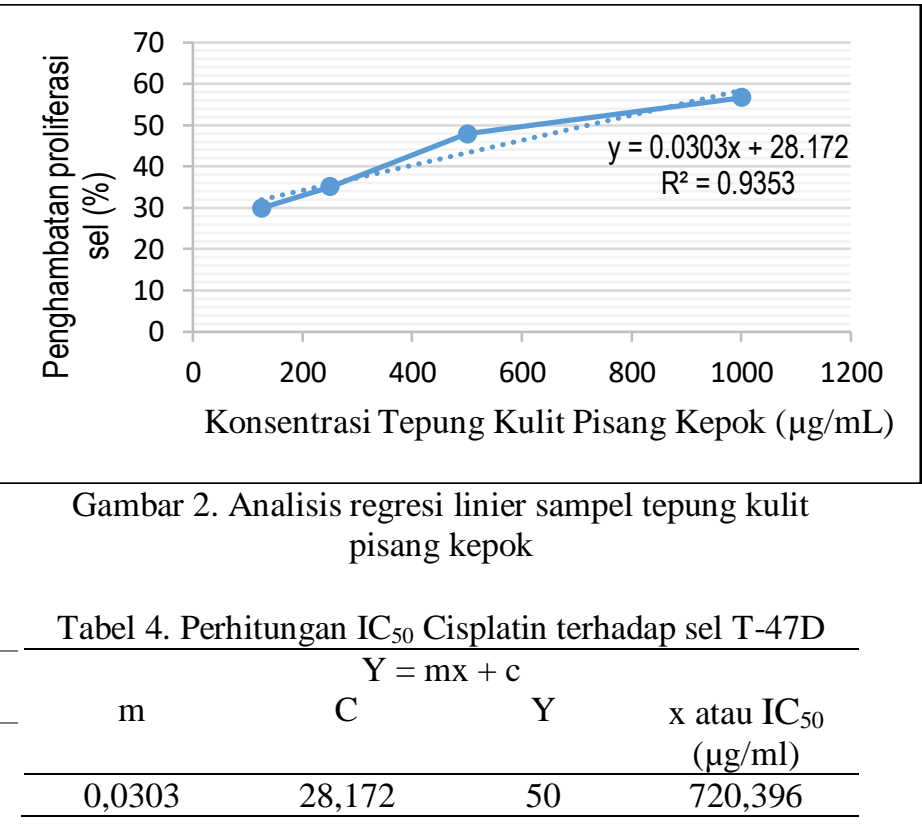

Dari hasil uji MTT Assay yang telah dilakukan, didapatkan tepung kulit pisang kepok mampu menghambat $50 \%$ pertumbuhan sel T-47D pada konsentrasi $1000 \mu \mathrm{g} / \mathrm{ml}$ dan nilai $\mathrm{IC}_{50}$ yang didapatkan adalah sebesar 720,396 $\mu \mathrm{g} / \mathrm{ml}$.

Menurut Kuete \& Efferth [25], tingkat kekuatan sitotoksik bagian tanaman yang dapat dikonsumsi berdasar nilai $\mathrm{IC}_{50}$ dikategorikan sebagai berikut.

Tabel 5. Tingkat kekuatan sitotoksisitas

\begin{tabular}{lc}
\hline \multicolumn{1}{c}{ Kategori } & $\mathrm{IC}_{50}$ \\
\hline Sitotoksik kuat & $<50 \mu \mathrm{g} / \mathrm{ml}$ \\
Sitotoksik moderat & $50 \mu \mathrm{g} / \mathrm{ml}-200 \mu \mathrm{g} / \mathrm{ml}$ \\
Sitotoksik rendah & $200 \mu \mathrm{g} / \mathrm{ml}-1000$ \\
& $\mu \mathrm{g} / \mathrm{ml}$ \\
Tidak sitotoksik & $>1000 \mu \mathrm{g} / \mathrm{ml}$ \\
\hline
\end{tabular}

Sumber: (Kuete \& Efferth, 2015) 
Tepung kulit pisang kepok yang diuji dengan MTT Assay tidak memiliki potensi antikanker terhadap sel T-47D karena sifat sitotoksik yang dimiliki rendah namun bersifat kemopreventif terhadap sel T-47D. Meskipun kulit pisang kepok memiliki kandungan antioksidan berupa senyawa polifenol sebanyak 7,71 mg GAE/g dan tannin $30,98 \mathrm{mg}$ GAE/g [9]. Dalam mekanismenya terhadap sel kanker payudara T-47D, polifenol bekerja dengan menghambat fungsi protein NF-kB (protein kompleks yang mentranskripsi DNA) dan enzim COX-2 (enzim yang berfungsi untuk merangsang pembelahan sel dan menginhibisi apoptosis). Tannin mampu menghambat respons stimulus p65, degradasi I $\mathrm{KB} \alpha$ (inhibitor NF-kB), dan menurunkan respons IL-6 sehingga aktivasi NF-kB pada sel kelenjar payudara terinhibisi [26] [27].

Penelitian yang dilakukan oleh Wardati dkk [28], terkait uji sitotoksisitas pada ekstrak tepung kulit pisang kepok menggunakan MTT Assay terhadap sel T-47D menghasilkan $\mathrm{IC}_{50} 220,375 \mu \mathrm{g} / \mathrm{ml}$. Ada beberapa faktor yang menyebabkan rendahnya nilai $\mathrm{IC}_{50}$ tepung kulit pisang kepok dari hasil uji MTT Assay terhadap sel T-47D jika dibandingkan dengan penelitian ekstrak tepung kulit pisang kepok. Salah satunya adalah bioavailabilitas dan bioaksesibilitas antioksidan yang dimiliki tepung kulit pisang kepok. Mikrostruktur bahan makanan mempengaruhi bioavailabilitas dan bioaksesibilitas antioksidan. Bioavailabilitas dan bioaksesibilitas antioksidan, yang dalam konteks tepung kulit pisang kepok ini adalah polifenol dan tannin, berperan sangat penting ketika senyawa tersebut sudah sampai pada target sel. Apabila konsentrasi yang sampai sedikit maka antioksidan tidak dapat bekerja secara efektif [29]. Sedangkan tepung kulit pisang kepok yang diolah dengan pemanasan oven kabinet dan pengayakan 80 mesh, masih memiliki kandungan yang bercampur dengan makromolekulmakromolekul lain seperti karbohidrat, lemak, protein, dan serat [30]. Apabila dibandingkan dengan ekstrak yang merupakan salah satu metode separasi untuk mengambil komponen tertentu pada suatu bahan, ekstrak tepung kulit pisang kepok struktur ekstrak tidak bercampur dengan makromolekul-makromolekul lain menyebabkan bioavaibilitas dan bioaksesibiltas aktioksidan pada ekstrak kulit pisang kepok lebih tinggi daripada tepung kulit pisang kepok [29].

Selain bioavaibilitas dan bioaksesibilitas, terdapat faktor kandungan-kandungan non-fenolik tepung kulit pisang kepok yang sulit untuk dipecah. Falodun dkk [31], melakukan uji proksimat terhadap tepung pisang Cardaba dengan 3 metode pengeringan yang berbeda yaitu freeze drying pada suhu $-50^{\circ}$ dan $0,1 \mathrm{~m} \mathrm{~Pa}$, cabinet drying pada suhu $60^{\circ} \mathrm{C}$ selama 24 jam, dan sun drying pada suhu $30^{\circ} \mathrm{C}-35^{\circ} \mathrm{C}$ selama 5 hari. Hasilnya menunjukkan bahwa pada metode cabinet drying memiliki kandungan pati resisten dan total pati paling tinggi diantara ketiga metode pengeringan yang diuji. Selain itu, serat kasar yang terdapat pada pemanasan cabinet drying lebih tinggi daripada pemanasan freeze drying yaitu $0,79 \%$ dibanding dengan $0,19 \%$ dari persen berat kering tepung pisang yang diuji. Pati resisten sulit untuk dicerna dengan sifat pati resisten adalah tahan terhadap degradasi secara fisik maupun enzimatik [32]. Pada mekanisme pencernaan manusia, pati resisten baru dapat dicerna di kolon untuk melalui proses fermentasi dan memproduksi short-chain fatty acids (SCFAs) [33]. Begitu pula dengan serat yang sulit untuk dicerna, serat baru dapat diabsorbsi di usus halus dan usus besar [34]. Oleh karena itu, pati resisten dan serat yang belum melalui sistem pencernaan dapat menghambat pelepasan polifenol karena polifenol terjebak di dalam struktur granula pati dan matriks serat yang sulit untuk dipecah [30] [35].

Berikutnya adalah faktor pemanasan yang dapat mempengaruhi efek sitotoksisitas tepung kulit pisang kepok. Pada penelitian Falodun dkk [31], terhadap 3 metode pengeringan yang berbeda, metode pengeringan yang memiliki kandungan polifenol paling tinggi adalah freeze drying. Metode freeze drying ini tidak membutuhkan suhu tinggi dan durasi yang lama, menyebabkan retensi polifenol lebih tinggi daripada metode cabinet drying dan sun drying. Senyawa polifenol sensitif terhadap perlakuan panas sehingga setelah dilakukan proses pengeringan kadarnya menurun akibat paparan suhu tinggi. Penelitian yang dilakukan oleh Syafrida dkk [36], terkait pengaruh suhu pengeringan terhadap aktivitas antioksidan daun dan umbi rumput teki pada 4 pemanasan yang berbeda yaitu pada suhu $27^{\circ} \mathrm{C}, 30^{\circ} \mathrm{C}, 40^{\circ} \mathrm{C}$, dan $50^{\circ} \mathrm{C}$ selama 24 jam. Didapatkan aktivitas antioksidan terus mengalami penurunan dengan suhu yang semakin tinggi. Hal ini dikarenakan kebanyakan golongan polifenol memiliki struktur dasar yang mudah teroksidasi apabila terpapar suhu tinggi [36].

Ada faktor-faktor tertentu yang mempengaruhi uji sitotoksisitas menggunakan MTT Assay, yaitu faktor endogendan eksogen serta lama waktu inkubasi yang dilakukan. Senyawa endogen dan 
eksogen dapat mempengaruhi perubahan kimiawi dari mekanisme enzimatik MTT Assay untuk membentuk kristal formazan. Sedangkan konversi kristal formazan sendiri sangat bergantung dengan tingkat metabolik sel dan jumlah mitokondria sel tersebut [37]

Tabel 6. Nilai $\mathrm{IC}_{50}$ uji viabilitas sel pada sel MCF-7

\begin{tabular}{lcc}
\hline Lama Inkubasi & $\begin{array}{c}\text { Ekstrak } \\
\text { Hexana }\end{array}$ & $\begin{array}{c}\text { Ekstrak B. } \\
\text { frutescens }\end{array}$ \\
\hline 2 x 24 jam & $22 \pm 0,04$ & $160 \pm 0,04$ \\
$3 \times 24$ jam & $10 \pm 0,33$ & $124 \pm 0,29$ \\
\hline
\end{tabular}

Sumber: (Shahruzaman dkk, 2019)

Selain dari mekanisme kerja uji MTT Assay sendiri, lama waktu inkubasi dapat mempengaruhi nilai $\mathrm{IC}_{50}$. Ditunjukkan pada Tabel 6, lama inkubasi untuk MTT Assay selama 3x24 jam menghasilkan nilai $\mathrm{IC}_{50}$ yang lebih tinggi daripada lama inkubasi selama $2 \times 24$ jam [38].

Selain faktor metode uji sitotoksisitas, adapula faktor sel kanker atau cell lines yang mempengaruhi nilai $\mathrm{IC}_{50}$. Cell spesific response atau respons spesifik sel merupakan ciri dari cell lines kanker. Pada aplikasi obat kanker, setiap cell lines memiliki respons fenotipik yang signifikan hanya pada masing-masing obat tertentu. Meskipun cell lines tersebut tersusun dari jaringan, spesies, ataupun histologi yang sama [39]. Perbedaan ini ditunjukkan pada tabel berikut.

Tabel 7. Nilai $\mathrm{IC}_{50}$ sel kanker menggunakan MTS Assay

\begin{tabular}{lcc}
\hline & $\begin{array}{c}\text { Ekstrak C. } \\
\text { melo }\end{array}$ & $\beta$-karoten \\
\hline HeLa & 23,649 & 51,760 \\
HepG2 & 110,403 & 270,419 \\
NIH3T3 & $50.645,994$ & 16,670 \\
\hline
\end{tabular}

Sumber: (Widowati dkk, 2015)

Dari tabel tersebut ditunjukkan bahwa respons inhibisi pertumbuhan setiap cell lines berbeda [40]. Hal ini menandakan, satu sampel obat atau produk antikanker memiliki variasi $\mathrm{IC}_{50}$ yang berbeda pada cell lines yang berbeda pula. Memungkinkan nilai $\mathrm{IC}_{50}$ tepung kulit pisang kepok berbeda pada cell lines selain sel kanker payudara T-47D yang digunakan pada penelitian ini.

\section{KESIMPULAN}

Berdasarkan penelitian yang telah dilakukan, dapat disimpulkan bahwa tepung kulit pisang kepok tidak berpotensi sebagai antikanker terhadap sel T-47D karena aktivitas antioksidan yang ditunjukkan lemah dan efek sitotoksisitas rendah.

Berdasarkan pada hasil penelitian yang telah dilakukan, disarankan beberapa hal untuk penelitian lebih lanjut sebagai berikut. (1) Perlu adanya penelitian lanjutan mengenai uji fitokimia pada tepung kulit pisang kepok. (2) Perlu adanya penelitian lanjutan mengenai metode penepungan yang berbeda untuk mencegah kenaikan kandungan pati resisten dan serat kasar. (3) Perlu adanya pengujian sitotoksisitas menggunakan cell lines yang berbeda.

\section{REFERENSI}

[1] Kementrian Pertanian , Statistik Produksi Hortikultura 2014. Jakarta: Kementrian Pertanian Republik Indonesia, 2015.

[2] N. Rajesh, "Medicinal Benefits of Musa Paradisiaca (Banana)," International Journal of Biology, vol. 2, no. 2, April 2017.

[3] E. S. Lolodatu, "Kualitas Non Flanky Crackers Coklat Dengan Variasi Subtitusi Tepung Pisang Kepok Kuning (Musa paradisiaca forma typica)," Universitas Atma Jaya, Yogyakarta, Tesis 2015.

[4] A. Sukowati and Sukarman, "Produksi Bioetanol Dari Kulit Pisang Melalui Hidrolisis Asam Sulfat," Universitas Lampung, Lampung, Tesis 2014.

[5] M. E Rustanti, "Potensi Kulit Pisang Kepok Kuning (Musa paradisiaca L.) sebagai Bahan Tambahan Dalam Pembuatan Es Krim," Universitas Sanata Dharma, Yogyakarta, Tesis 2018.

[6] Azza and Ferrial, "Nutritional and AntiNutrtional Composition of Banana Peels as Influenced by Microwave Drying Method," International Journal of Nutrition and Food Engineering , vol. 11, no. 12, 2017.

[7] A. C. C. Egbuonu, W. O. Nneji, and C. A Ukasoanya, "Comparative Evaluation of Some Nutrient Contents and Antifungal Properties of Ground Musa paradisiaca (Plantain) Peels and Leaves," British Journal of Applied Science \& Technology, vol. 19, no. 1, 2017.

[8] M. Roy, A. Mukherjee, S. Mukherjee, and J. Biswas, "Phytochemicals as an adjuvant in leukemia therapy," semanticscholar, pp. 1-10, 
2017.

[9] E. Agama, J. A. S. Barajas, R. Veles, and G. A. G. Aguilar, "Potential of plantain peels flour ( Musa paradisiaca L.) as a source of dietary fiber and antioxidant compound," Journal of Food, vol. 14, no. 1, 2015.

[10] International Agency for Reasearch on Cancer. (2019, Mei) Global Cancer Observatory. [Online]. https://gco.iarc.fr/today/data/factsheets/popula tions/360-indonesia-fact-sheets.pdf

[11] K. B. Arun; F. Persia; P. S. Aswanthy; J. Chandran; M. S. Sajeev et all, "Plantain peel a potential source of antioxidant dietary fibre for developing functional cookies," Journal Food Sci Technol, vol. 52, no. 10, Oktober 2015.

[12] R. Futeri and Pharmayeni, "Substituting Wheat Flour with Banana Skin Flour from Mixture Various Skin Types of Banana on Making Donuts," International Journal on Advanced Science, Engineering and Information Technology, vol. 4, no. 2, 2014.

[13] D. Tristantini, A. Ismawati, B. T. Pradana, and J. G. Jonathan, "Pengujian Aktivitas Antioksidan Menggunakan Metode DPPH pada Daun Tanjung (Mimusops elengi L)," in Prosiding Seminar Nasional Teknik Kimia "Kejuangan", Yogyakarta, 2016.

[14] B. Arwan, "Uji Toksisitas Fraksi Ekstrak Etanol 70\% Akar Parangromang (Boehmeria Virgata (Forst) Guill) Terhadap Larva Udang (Artemia Salina Leach) Dengan Menggunakan Metode Brine Shrimp Lethality Test (BSLT)," UIN Alauddin, Makassar, Skripsi 2017.

[15] Food and Agriculture Organization of United Nations dan WHO. (2018) Codex Alimentari International Food standards. [Online]. http://www.fao.org/gsfaonline/docs/CXS_192 e.pdf

[16] M. Marshall and A. S. P. Grotheer. (2016) IFAS Extension. [Online]. https://edis.ifas.ufl.edu/pdffiles/FY/FY73100. pdf

[17] D. H. Wardhani, A. e. Yuliana, and A. S. Dewi, "Natrium Metabisulfit Sebagai AntiBrowning Agent Pada Pencoklatan Enzimatik Rebung ORI (Bambusa Arundinacea)," Jurnal Aplikasi Teknologi Pangan, vol. 5, no. 4, 2016.

[18] A. N. Syahruddin, I. A. Ibrahim, and
Nurdiyanah S, "Identifikasi Zat Gizi dan Kualitas Tepung Kulit Pisang Raja (Musa Sapientum) dengan Metode Pengeringan Sinar Matahari dan Oven," Media Gizi Pangan, vol. 19, no. 1, 2015.

[19] S. I. Behiry et all, "Antifungal and Antibacterial Activities of Musa paradisiaca L. Peel Extract: HPLC Analysis of Phenolic and Flavonoid Contents," MDPI, vol. 7, no. 4, Maret 2019.

[20] Z. B. Ahmed et al., "Seasonal, gender and regional variations in total phenolic, flavonoid, and condensed tannins contents and in antioxidant properties from Pistacia atlantica ssp. leaves," Journal Pharmaceutical Biology, vol. 55, no. 1, 2017.

[21] F. Shahidi and J. D.Yeo, "Insoluble-Bound Phenolics in Food," Molecules, vol. 21, no. 9, 2016.

[22] A.E. Quirós-Sauceda; J.F. Ayala-Zavala; S.G. Sáyago-Ayerdi; R. Vélez-de la Rocha, "Added dietary fiber affects antioxidant capacity and phenolic compounds content," Journal of Applied Botany and Food Quality, vol. 87, 2014.

[23] R. Chrisnasari and Sudono, "The Proximate and Phytochemical Properties of Red Pitaya (Hylocereus polyrhizus) Stem Flour and Its Potential Application as Food Products," Journal Tropical and Agricultural Science, vol. 42, no. 3, 2019.

[24] S. Velumani, "Phytochemical Screening and Antioxidant Activity Of Banana Peel," IJARIIE, vol. 2, no. 1, 2016.

[25] V. Kuete and T. Efferth, "African Flora Has the Potential to Fight Multidrug Resistance of Cancer," BioMed Research International, 2015.

[26] M. Carocho and I.C.F.R Ferreira, "A review on antioxidants, prooxidants and related controversy: Natural and synthetic compounds, screening and analysis methodologies and future perspective," Food and Chemical Toxicology, vol. 51, 2013.

[27] D. A. Kim; H. S. Choi et all, "Tannic acid attenuates the formation of cancer stem cells by inhibiting NF-кB-mediated phenotype transition of breast cancer cells," American journal of cancer research, vol. 9, no. 8, 2019.

[28] F. Wardati, K. Holil, and U. Syarifah, "Cytotoxicity Test on Breast Cancer Cell 
Lines T-47D treated with Pisang Kepok Peel Extract (Musa balbisiana)," Bioinformatics and Biomedical Research Journal, vol. 1, no. 3, 2018.

[29] EBrglez Mojzer, Masa Knez Hrncic, Mojca Skerget, Zeljko Knez, and Urban Bren, "Polyphenols: Extraction Methods, Antioxidative Action, Bioavailability and Anticarcinogenic Effects," Molecules, vol. 21, no. $7,2016$.

[30] Hugo Palafox-Carlos, Jesús Fernando AyalaZavala, and and Gustavo A González-Aguilar, "The Role of Dietary Fiber in the Bioaccessibility and Bioavailability of Fruit and Vegetable Antioxidants," Journal OF Food Science, vol. 76, no. 1, 2012.

[31] Adedolapo Ibironke Falodun, Helen Ayo Omogie, and Olugbenga Olufemi Awolu, "[31] Falodun, A.I., Ayo-Omogie, H.N. and Awolu, O.O., 2019. Effect of Different Drying Techniques on the Resistant Starch, Bioactive Components, Physicochemical and Pasting Properties of Cardaba Banana Flour. Acta Universitatis Cibiniensis. Series E: Food," Acta Universitas Cinbiniesis Series E; FOOD TECHNOLOGY, vol. 23, no. 1, 2019.

[32] Akmal Novrian Syahruddin, Irviani A. Ibrahi, and Nurdiyanah S, "Identifikasi Zat Gizi Dan Kualitas Tepung Kulit Pisang Raja (Musa sapientum) Dengan Metode Pengerigan Sinar Matahari Dan Oven ," Media Gizi Pangan, vol. 19, no. 1, 2015.

[33] Xuehong Li, "Resistant Starch and Its Applications," Functional Starch and Applications in Food, 2018.

[34] Devinder Dhingra, Mona Michael, Hradesh Rajput, and and R. T. Patil, "Dietary fibre in foods: a review," J Food Sci Technol, vol. 49, no. 3, 2011.

[35] Perez-Hernandez LM et al., "Starch Digestion Enhances Bioaccessibility of AntiInflammatory Polyphenols from Borlotti Beans (Phaseolus vulgaris).," Nutrients. , vol. 12, no. 2, 2020.

[36] Mulia Syafrida Sri Darmanti Muniffatul Izzati, "Pengaruh Suhu Pengeringan Terhadap Kadar Air, Kadar Flavonoid dan Aktivitas Antioksidan Daun dan Umbi Rumput Teki (Cyperus rotundus L.)," Bioma, vol. 20, no. 1, 2018.

[37] van Tonder A, Joubert AM, and Cromarty $\mathrm{AD}, \quad$ "Limitations of the 3-(4,5dimethylthiazol-2-yl)-2,5-diphenyl-2H-

tetrazolium bromide (MTT) assay when compared to three commonly used cell enumeration assays.," BMC Res Notes, vol. 8, no. $47,2015$.

[38] S. H. Shahruzaman; M. F. Mustafa; S. Ramli; S. Maniam; S. Fakurazi \& S. Maniam, "The cytotoxic effect and glucose uptake modulation of Baeckea frutescens on breast cancer cells," BMC Complementary and Alternative Medicine, vol. 19, 2019.

[39] Niepel $M$ et al., "Common and cell-type specific responses to anti-cancer drugs revealed by high throughput transcript profiling.," Nat Commun, vol. 8, no. 1, 2017.

[40] Wahyu Widowati, Rahma micho Widyanto, Dian Laksmitawati, and Erawijantari pande putu, "Phytochemical, Free Radical Scavenging and Cytotoxic Assay of Cucumis Melo L. Extract and $\beta$-Carotene," Journal of Advanced Agricultural Technologies, vol. 2, no. 2, 2015. 